\title{
The family strengths in the context of psychoactive substance dependence
}

\author{
As forças familiares no contexto da dependência de substâncias psicoativas \\ Las fuerzas familiares en el contexto de la dependencia de sustancias psicoactivas
}

Maria Izabel Sartori Claus $^{1}$ (D)

Sonia Regina Zerbetto ${ }^{1}$ (1)

Angélica Martins de Souza Gonçalves ${ }^{1}$ (I)

Tanyse Galon ${ }^{2}(1)$

Letícia Grazielly Zanon de Andrade ${ }^{1}$ (i)

Fernando Calzavara de Oliveira ${ }^{1,3}$ (iD)

1. Universidade Federal de São Carlos.

São Carlos, SP, Brasil.

2. Universidade Federal do Triângulo Mineiro -

UFTM. Uberaba, MG, Brasil.

3. Centro de Atenção Psicossocial-Álcool e

Drogas. São Carlos, SP, Brasil.
Corresponding author:

Maria Izabel Sartori Claus.

E-mail: bebelclaus@hotmail.com

Submitted on $06 / 20 / 2018$.

Accepted on 09/14/2018.

DOI: 10.1590/2177-9465-EAN-2018-0180

\section{Abstract}

Objective: To apprehend the perception of relatives of psychoactive substances dependents about their facilitating strengths to deal positively with the adversities from this context. Method: Qualitative and descriptive study developed between July/2016 and August/2017 at Psychosocial Care Center Alcohol and Drugs of a city on the countryside of São Paulo, through a semi-structured interview for data collection. Eight family members of chemical addicted participate. The interviews were recorded by audio, transcribed and analyzed by content analyze technique, thematic category. Results: The relatives recognized that their facilitating strengths permeated through the religiosity and spirituality, beliefs systems, support from the specialized mental health service support and of friendship, whilst social support network. The strengths also depended on the cohesion and assertive communication of the family. Conclusion: The facilitating strengths recognized by relatives help them deal positively with adversities in the chemical addiction context, strengthening the familiar resilience.

Keywords: Substance-Related Disorders; Family Relations; Mental Health; Resilience, Psychological.

\section{Resumo}

Objetivo: Apreender a percepção dos familiares de dependentes de substâncias psicoativas sobre suas forças facilitadoras para lidarem de maneira positiva com as adversidades provenientes deste contexto. Método: Estudo qualitativo, descritivo, realizado entre Julho/2016 a Agosto/2017 no Centro de Atenção Psicossocial Álcool e Drogas de uma cidade do interior paulista, através de entrevista semiestruturada para coleta de dados. Participaram oito familiares de dependentes químicos. As entrevistas foram gravadas por áudio, transcritas e analisadas pela técnica de análise de conteúdo, categoria temática. Resultados: Os familiares reconheceram que suas forças facilitadoras perpassaram a religiosidade/espiritualidade, os sistemas de crenças, o apoio do serviço especializado de saúde mental e as amizades, enquanto rede de apoio social. As forças também dependeram da coesão e comunicação assertiva da família. Conclusão: As forças facilitadoras reconhecidas pelos familiares os auxiliaram a lidar positivamente com as adversidades no contexto da dependência química, fortalecendo a resiliência familiar.

Palavras-chave: Transtornos Relacionados ao Uso de Substâncias; Família; Relações Familiares; Saúde Mental; Resiliência Psicológica.

\section{REsumen}

Objetivo: Aprehender la percepción de los familiares de dependientes de sustancias psicoactivas sobre sus fuerzas facilitadoras para lidiar, de manera positiva, con las adversidades provenientes de ese contexto. Método: Estudio cualitativo, descriptivo, realizado entre Julio/2016 y Agosto/2017 en el Centro de Atención Psicosocial Alcohol y Drogas de una ciudad del interior de estado de São Paulo, a través de una entrevista semiestructurada para la recolección de datos. Participaron ocho familiares de dependientes químicos. Las entrevistas fueron grabadas en audio, transcritas y analizadas según la técnica del análisis de contenido, categoría temática. Resultados: Los familiares reconocieron que sus fuerzas facilitadoras pasaron por la religiosidad/espiritualidad, por los sistemas de creencias, por el apoyo del servicio especializado de salud mental y por las amistades, como la red de apoyo social. Las fuerzas también dependieron de la cohesión y comunicación asertiva de la familia Conclusión: Las fuerzas facilitadoras reconocidas por los familiares les ayudaron a lidiar positivamente con las adversidades en el contexto de la dependencia química, fortaleciendo la resiliencia familiar.

Palabras clave: Trastornos Relacionados con Substancias; Relaciones Familiares; Salud Mental; Resiliencia Psicológica. 


\section{INTRODUCTION}

The problematic of the psychoactive substances consumption (PASs) affects the life and the interpersonal relationships among chemical dependents, family and community, ${ }^{1}$ requiring approaching such theme in the familiar context.

Studies about family and dependence of PASs point out the familiar functionality in the negative aspects of the familiar interaction, ${ }^{2-5}$ while its strengths and its potential have not been perceived and valued. ${ }^{6}$ Study about family resilience, in the perspective of health professionals specialized in PASs, shows that families bring forward positive forces, therefore facilitating forces for its behavior. These forces cover the family organization, through union towards the resolution of the problem, as well the belief in the hope of cure of its dependent relative and its perseverance in the treatment. ${ }^{7}$

In the clinical practice of the family nursing, the nurses as they help the family in the acknowledgment and apprehension of their own positive forces, they potencialize and empower them. ${ }^{8}$ These professionals, by potentializing, subsidizing and complimenting the strengths of the family, simultaneously, they instrumentalize it to discover existing resources and/or not yet acknowledge, as well as learning new competencies and skills or enhancement in the process of the family relationships.

The relevance of this study justify itself though the assumption of the existence of the family strong points, as a collective, and the family members, while individuals, to the effective coping of the daily adversities in the drugs context. The apprehension of the facilitating forces to the assertive coping of the daily situations lived by the relatives of the PASs dependent will subsidize the nurses to strengthen their skills at effectively and assertively answer, as a functional unity.

Therefore, which are the facilitating forces acknowledged by the relatives of the PASs dependent that capacitate them to deal with the demands from this living in a more positive manner?

The objective of this study consists in learning the perception of the psychoactive substances dependent's relatives about their own facilitating forces to deal with the adversities coming from this context in a positive fashion.

\section{METHOD}

Qualitative and descriptive study, having as theoretical framework the facilitating family forces. In the perspective of the positive psychology, the family forces are defined as the resources utilized by the family, that capacitate it in the assertive handling of the adversities and demands faced in everyday life,, 89 in a way to improve the functionality and integrality of the family. This forces or strengths are acknowledge as family competences in the process of facing the difficulties and challenges, which are them transformed into learning and growing opportunity. ${ }^{10}$

The positive strengths are identified through activities and developed skills which involve: set aside living time between family members to share and discover affinities; share the affection and the learning coming from accumulated knowledge by collective surpassed difficulties; ${ }^{8,11}$ promote, favor, develop the capacity to seek for help and understand the spiritual needs of the family, ${ }^{11}$ communicate in a effective and assertive manner, as well as create and sustain constructive communitarian relationships, among others. ${ }^{12}$

The research was conducted in the period between July of 2016 and August of 2017, with intentional samples of eight relatives, being three fathers and five mothers, from six families of psychoactive substances dependents being treated at the Psychosocial Care Center Alcohol and Drugs (CAPS AD, as originally in Portuguese) of a city in the Countryside of São Paulo. A total of twenty families were identified by the health team of the respect service, however seven of those were no longer linked to CAPS AD, there was not possible phone contact with four families and three refused taking part in the research. The health team performed the intermediation with the families according to the inclusion criteria: family members over 18 years old, blood related degree of kinship, those who live with the dependent at least twice a week and were goes of the service at least once a month. Relatives that were intoxicated by the consumption of psychoactive substances and that did not support the treatment of its relative dependent of PASs were excluded from this study.

After the phone contact, semi-structured interviews were conducted, being the first three interviews realized by two researchers, while the remaining by one only researcher. The relatives from the same family were interviewed together, but each family interviewed in different moments, as the place consisted in the home environment or the CAPS AD. It was sought to apprehend the sociodemographic characterization of the relatives, the relational and functional context of the family and their facilitating strengths in the effective management of the daily difficulties.

The interviews lasted for around 2 hours and were all record by audio and, posteriorly, transcribed. For the data analysis it was used the content analysis technique, thematic category. ${ }^{13}$ The interviews were read deeply many times, identifying, grouping and codifying the textual essays (sentences) of the report from the interviews. The textual cutouts pointed the first subjects about the resources and manners utilized by the families in the process of positive toiling with the adverse situations in the relations inside and outside of the family, recognized as facilitating forces. The cutouts were aggregated accordingly to the correlate subject, from the same semantic content, whose presence or relevance could be related to the object of study, ${ }^{13}$ finalizing them in four categories: 1) The family strength comes from religious and spiritual practices;2) The family strength comes from the support of the CAPS AD and the social support network; 3) The family strength comes from family beliefs; 4 ) The family strength comes from the family relationships. In the treatment of the results, there were inferences and interpretations backed by the theoretical 
concept of facilitating family strengths and scientific evidences in this theoretical perspective.

Ethical principles from research involving human beings were respected, according to Resolution 466/12, as this study approved by the Ethics Committee on Human Research, notion n. 1.613.175 de 28/06/2016, CAAE 56505416.7.0000.5504. The participants sign the Informed and Free Consent Form.

The depositions from the interviewed were codified with the letter $\mathrm{F}$ for family, followed by a number from 1 to 6 accordingly to the order the families were interviewed, as well as followed by the letter $\mathrm{M}$ for mother or FA for father, followed by the same number corresponding to the family.

\section{RESULTS}

As for the characterization of the families, four of them had a nuclear configuration (father, mother and children) and two single parental (mother and children). The age range varied between 51 and 76 years old. Regarding religion, four families were Catholic, one Adventist and one Evangelical. The kinship degree of the interviewed relatives with the chemical dependent consisted in fathers and mothers.

Hereafter will be presented the categories obtained from the analysis.

\section{The family strength comes from religious and spiritual practices}

This category encompassed religious and spiritual practices performed by the families that enveloped: prayers, penitence and fasting, attending religious institutions (churches), seeking the Divine word and demonstrate feeling of faith in God, those which acted as strategies to give them strength.

The prayers were recognized by the families as a connection path, dialog and approximation with a Superior power, which listen them. The more the family pray, more strength it receives, helping them resist the adversities and remain in the daily fight.

[...] The prayer is to strengthen and ask for more help for us [family] being strong to move forward, to this fact [living with a dependent], right? [...] Yes, because we [couple] were to strayed away from God and that which we seek to gain strength, that God which strengthen, right (F2FA2).

[...] Prayer is a powerful thing; I believe in God, I believe and I'm certain that He can hear us through prayer [...] (F3FA3).

The prayers were also given meaning by the families accordingly to the places they were practiced. For them, pray at home and at the religious institution increased the faith of the family and facilitated the obtainment of God's mercy.
[...] It's praying at home, seeking prayer in the church, do what we have to do, we are doing it, holding on to God tight, asking a lot for God, because its only God to have mercy. Because it is not easy... Living with a drug user is not easy (F1M1).

To one father, the religious institution made possible for him to listen to the Divine word, which strengthen, calmed and promoted learning. The messages transmitted by the religious leader were recognized as a way of God communicating with the family, give them wisdom and control.

[...] there are many things happening in our lives, that there [church] at the time it seems like the priest mention that subject, and it seems that there you are putting things in your head, you become calmer, you will not want to fight [...] We [couple] go to the church, learn how you can have control inside your house ... [...] (F1FA1).

The fasting, as a penitence practice, and the prayers were identified in the relatives perception as promoting strategies to give tranquility and patience for the families; as well as the belief that the dependent would be calmer, therefore improving the family relationships.

[...] we [couple] are feeling that we are more patient [...]... That is praying, fasting and being patient; we have to be patient to go on, because otherwise we don't live, no (F1M1).

[...] And we [couple] are there, asking for God, to give him calm [dependent], understood? (F1FA1).

[...] The prayers give me strength to face all this; they calm me $[\ldots]$ (F6M6).

In the family perception, fasting means asking for God that the dependent free itself from the dependence in PASs, recover and change its own lifestyle and behavior. This family believed that everything in life demands sacrifice.

[...] We [couple] want that him [dependent] live, right, at least that God give him life, so what that we do? We are fasting with the intention that [name of the dependent] become disgust, not only from alcohol, from drugs, but from cigarette too. [...] Because everything in life demands sacrifice (F1M1).

[...] Ask for his liberation [dependent], for him to be set free [...] And give him a better life, which he changes, that he starts to think about looking for a service, registered employment (F1FA1). 
As for the spiritual practice, it stands out the conception that the faith in God move the families, strengthens then so they can strengthen its loved one.

[...] What strengthens me... [...] First of all, faith in God, right? [...] And it's God that gives me strength too; that for everything I've been through, I go though and I go on... [...] He strengthens me so I can strengthen he [dependent] which is having the power to fight for him. [...] This is what gives me power, it is the God that I have and the will that I have to see my son recovered, that's what gives me power (F5M5).

\section{The family strength comes from the support of the CAPS AD and the social support network}

This category evidenced the role that the Psychosocial Care Center Alcohol and Drugs has in the family fortification in two main circumstances: by providing treatment and support biopsychosocial as well as making knowledge, learning and family guidance possible.

Another resource acknowledge by the families constituted in the support outside of the family group, across friendship networks and in the researchers, comprehending the moment of the interview as unburden, hosting and listening opportunities.

The family group and the individual care were identified as supporting resources from CAPSAD to the family members on this study. The respective service offers health care to the dependent and relatives.

\section{[...] those who have more accompaniment [at CAPS AD] it's me more than him [dependent]; seeking help and seeking strength [...] [...] another thing that gives me much strength are the meetings [of the family group [...] because for each step we take here [CAPS AD], together with them [professionals at CAPS AD], we are learning and we are getting stronger (F5M5).}

The family members pointed out that the group and private treatment, accomplished at the CAPS AD, compose a source of strength for them by providing guidance, information, support and learning. Such resources encompass the handling of the dependent and better understanding the scope of the psychoactive substances dependence.

[...] when I first came to CAPS, then I started taking part in the meetings [family group], do the follow up with the [psychologist name] in the beginning, and the [psychologist name] helped a lot in making me stronger and start learning how to deal with that [chemical dependency situation]! [...] So, it's about learning [...] (F5M5).
As for the support outside of the family, friends offer support to the family by listening, comfort words, companionship and simple attitudes like a hug. Besides that, they express messages of incentive to the family perseverance, fighting spirit and strength. The moment of the interview was also perceived as therapeutic and empowering, for it was an opportunity to unburden and subsidy the family in the discovery of the strengths it has.

[...] We [couple] seek strength in faith, faith in God, in the people that are there with us always offering support [...] when someone gives you some strength, a hug, a word of advice, comforts you a little, that helps you [...] Sometimes without saying anything, just the companionship helps (F2M2).

[...] but all the help here is welcomed, you [interviewers], thanks you for the opportunity that you give me, it was not me that is causing something to you, this help is being you, I can say right? This is good, we putting it out things that we have. [...] As for the friends, they motivate us, say that we have to fight, persist, and cannot give up. Good friends come and say those things right (F3FA3).

\section{The family strength comes from family beliefs}

This category approached the conception of the family members about their own strengths, which were originated from their beliefs that involved perseverance, struggle, hope and faith in the recovery of the sick relative.

Some relatives emphasized that their strengths, frequently, come from the belief that they should not give up upon the person they love.

[...] We [couple] have to be persevering [...] we cannot give up on who we love, we should never give up. In the magazine is written: 'Never give up on who you love'; if we really are people from God, we should never give up (F1M1).

To one of the mothers of the dependent, the belief was ingrained to the idea that while there is life, there is hope. The report of the family merged the perspectives of life and hope, both hers as the dependents. For her, the family needs to keep the faith and the fight up, to conquer the recovery of its relative. The family believed that they cannot give up while there is life.

While I have strength, I will fight to take him out [dependent] of the drugs. [...] But there is still hope because there is life, right? And I think that while there is life, there is hope. And I will fight, while God grant me life, I will fight to see if I can make him [dependent] a good man [...] While there is life, there is hope (F4M4). 


\section{The family strength comes from the family relationships}

This category pointed out that the family strength depended on the interaction and communication between the parents, as well as between the parents and the dependent.

In the relationship process, the families pointed out the need to manage situations of conflict with the dependent by dialog and the establishment of rules and limits.

[...] And he [dependent] is a difficult person to deal with, you know? You have to talk with him, you have to talk very calmly with him [...] That the [name of the dependent] draws too much attention doing thing, hitting his head against the wall, these things, I told them [professionals at CAPS AD] [...] What we [couple] say, we have to be firm, if we say no, it's no and that's it. I'm not backtracking on my word [...] (F1M1).

[...] It's about being present, talk a good deal with him [dependent], dialog and try to help and don't massacre, right? (F6M6).

The family members recognized that the cohesion and mutual support in the marital system were unleashed by the coping process of the PASs dependence situation, creating a partnership relationship, of reciprocal cooperation and motivation.

\section{[...] before, we [couple] were kind of disunited, me and him} [husband] [...] we are together now, we are much more united one another, you know? [...] Because I think that without him [husband], I don't know if I would be putting up with [name of the dependent] [...] But I think that, like, I think that we are more united. We got united, a positive thing that happened, our union (F1M1).

[...] My husband also has been a great partner to me, many times he [husband] saw me very sad, he always tries to cheer me up, you know (F4M4).

The family cohesion was also recognized as a mechanism of positive strength towards facing the drug problematic, including for its recovery.

[...] Positive forces, I believe that's what we [family] are working hard to do [...] My proposal with [name of the dependent] is to tread this path and face the difficulties together with him [dependent]; [...] So, the family has a union right, and so on, and even more united now that the family is turned to the [name of the dependent], we have intensified a request in the favor of [name of the dependent], so he [name of the dependent] can win and get over this (F3FA3).
A mother related that sharing cheerful moments minimizes negative emotions and feelings.

Sp, we try to be happy, play a little, because them, we have to laugh ... [...] Now, he [husband] his good mood is back again (F1M1).

The family pointed out that communication with the dependent of PASs must be calm, with proper low intonation in order to avoid conflicts, and also encourage and strengthen him.

[...] Speak more calmly, explain reality with a lower tone right [...] And as parents, we try to explain, give explanations about what we lived, because the young is always thinking that he talks and knows everything [...] Today with wisdom I seek to pass on to him, with soft words, a short version o what I lived and of what needs to be done. So it's like that, give us a good dialog (F2FA2).

\section{DISCUSSION}

The families encompassed by this study identified facilitating strengths coming from religious and spiritual practices, from the health service and social network, from family beliefs and from intra-family relationships. They also recognized the prayer as a strengthener resource, by allowing a communicative channel with a Superior Being that is always there, listens and welcomes their pleas or thanks. Studies show that praying in Christian families allows communication with God, spiritual fortification and resilience before adverse situations. ${ }^{14,15}$ The feeling of God's presence or a Superior Being in someone's life certifies that they are not alone or helpless. ${ }^{14}$

The frequency of this religious practice and the local that it takes place also made possible conditions to increase the family's member faith, obtain Divine mercy and have recovery expectations for the dependent relative. The studies stress that faith, manifested many times through prayer, promotes strength and support in people's daily life. ${ }^{14}$

It was noticed that to relatives taking part in this study, the prayer promoted approximation with God, creating a partnership and attachment between both, in the perspective that He has compassion, grants mercy, decrease suffering and recover the sick relative.

The data infers it is through prayers that the family pleads and thanks the Superior Being for the recovery of the drug dependent. Studies show that prayer constitute a therapeutic instrument or resource ${ }^{15-17}$ both to the ill relative and to the family, as it promotes tranquility, inner peace, minimizes suffering, provide confort ${ }^{18}$ and hope in the recovery. ${ }^{14}$

The relatives taking part in this study recognized that the religious environment facilitate the access to messages of Christian content, transmitted through its representatives, which 
provide strength, tranquility and teachings. The data corroborate study about spirituality and religiosity that shows that the messages from Sacred Books as sources of learning, comfort ${ }^{15}$ and support to the person's change of behavior. ${ }^{19}$

Therefore, the religious listening consists in strategies that promote calm, learning, strength to the family deal with the addiction to psychoactive substances problematic, as well as review posture and attitudes facing a moment of crisis. Many families find strength, comfort and guidance in the moments of adversity through their cultural and religious traditions. . $^{6,15,20}$

Besides prayers, penitence by fasting was recognized by family members as a strategy to provide patience and wisdom and recovery to its addicted relative.

The act of fasting was seen by the Catholic family in this study as a form of penitence and sacrifice, that is, to crave something in life, for example, the liberation of the relative from drugs, sacrifices and struggle are necessary. However, it was also noticed an implicit meaning in this act, that is, to crave the lifestyle change of the sick relative, through the attainment of the Divine Grace. Study about the relationship between the Catholic Religion and feeding points out that the act of fasting provides "the experience of feeding from spirituality and not from what is physical", constituting itself in a penitence to reach the Divine Grace. ${ }^{21: 77}$

One can infers that for the family of the PASs addicted, the prayer and the fasting become strategies of spiritual nature to achieve discernment and clarity in situations of conflict, with the purpose of stopping impulsive actions. Besides that, through those practices the family asks God for the recovery of its loved one.

The spiritual practices to the families in this study value the faith in God, which pushes the family and keeps it persevering and strengthen. Such data corroborate scientific evidences in which the faith helps the family believes and gives it a positive perspective about the future, strengthening their resilience. ${ }^{6,20}$ Thereby, faith can be considered positive energy, in other words, fuel to the family coat itself with strength, be hopeful, keep itself fighting, face adverse situations and not discourage facing obstacles in the context of chemical dependency.

Stands out that to the families in this study, the strength coming from religion had a connotation to move forward to reach a transcendental state, in which the spirituality was mediated by dogmatic practices from certain religion.

Accordingly to the second category in this study, another force recognized by the family members came from the psychosocial and psycho educational support from CAPS $A D$, through family groups and one-on-one care offered to the dependent and its relatives, also constituting a source of knowledge, learning and guidance to the family. Such data corroborate North American study about family strengths that point out people's competences in facing difficulties, being transformed in learning and growing opportunities. ${ }^{10}$
Studies bring forward that, to some families, the CAPS $A D$ constitute a place of listening, care, personal experiences sharing, self knowledge promotion and that complements the social familiar web. Other than that, it consists in a place where the family can be taken care of and learn to look out for others and itself. ${ }^{22,23}$ Scientific evidences stress that the family group meetings constitute empowering spaces and instrumentalization, offering them information, guidance and clarification upon psychoactive substance dependency, as well as competences and skills in handling the dependent at home. . $3-26^{-26}$

The family support through friendships and the moment of the interview with the researches were relevant to the fortification of the family, for they constitute unburden, care and listening opportunities. As a matter of fact, the informal social network and not professional can constitute important protecting factors by offering instrumental, emotional and community connection support to the family members, ${ }^{6,20,27}$ as well as financial assistance. ${ }^{28}$ The strength of the family, obtained through the support of the relationship with friends, can encompass material goods, financial and emotional support, minimizing de helplessness feeling.

In the third category, the reports from the family members in this study demonstrated the appreciation of a system of beliefs shared by the members, which was recognized as fortitude generator for the family. They emphasized the perseverance in keep fighting and not give up on their loved one, in this case, the dependent of PASs. In fact, the literature shows that perseverance consists in one of the fundamental elements to face and overcome adversity. ${ }^{6,29}$

The perseverance is moved by hope, which stimulates the family to fight for its loved one and for its rehabilitation and recovery. However, having hope also promotes perseverance. It s perceived that the families believe in the perspective that "while there is life, there is hope". The data corroborates studies that shows that perseverance and hope are inserted in the construction of family strength. ${ }^{6,29}$ It is inferred that, likely, this faith and attitude of the relatives are related to the affection among them, positively stimulating them in the process of coping, persistence and fighting against the context of chemical dependency.

Hope is essential to the spirit, as it promotes positive energy and mobilizes forces to overcome adversities. Hope also is based on faith, which allows the families in this study to visualize a better future, no matter how gloomy the present is. In problems saturated conditions, is essential that the health professionals revive the hope in this families, even through signs of despair. ${ }^{20}$ Such interventions can help the relatives to identify possibilities, appropriate the potential resources and strive to overcome the obstacles. Hoping for a better life to their kids keep many parents fighting, expecting to avoid defeats unleashed by disappointing of their own lives ${ }^{20}$ or one of its members. 
The last category explored the strength coming from the intrafamily relational processes, that is, the intra-marital interactions, both among parents and dependent member. To the relatives, the facilitating strengths depended on effective and efficient interactions through assertive communication. Study that describes cognitive-behavioral strategies utilized by dependents of psychoactive substances' family members in a risk situation shows that the improvement in the communication ability and assertiveness unleashed the approximation between family members and, consequently, aid and support of the family unit to the drug dependent. ${ }^{30}$ The family, by learning assertive communication and skills and interacting with family members of drug dependent people, develops and exercise capacities and competences to manage conflict situations, establish rules and limits to make feasible greater serenity coexisting with the chemical dependent, reinforcing scientific evidences. ${ }^{31,32}$

The coping process for conflicting situations in the context of PASs dependence by the marital subsystem promoted its union and mutual support, on the contrary of what happens when the analysis is based in a shortfall family model. Such model focus the dysfunctional family, identifying the marital union as a negative triangulation, when the spouses unite to face the ill relative. ${ }^{3}$

The data presented by this study reported the couple based on the facilitating strength perception of the union against the adverse situation to help the son. On the other hand, some studies, ${ }^{3,4}$ approaching restrictive strengths, shows that the ill relative by starting the treatment breaks free from the pre-established homeostasis, requiring the marital subsystem to change attention focus. Thus, this relative by leaving the attention spot, promotes the displacement of that attention to its own relationship, identifying conflicts, those which can be kept, putting at risk the marital relationship; ${ }^{3}$ or can be analyzed and reviewed, to assertive change the behavior. It was noticed that the need to seek for effective solutions to the adverse situation provided effective relational and communicational approximation between the couples. In fact, the assertive communication potencialize the family chesion ${ }^{33}$ and the resolution of conflicts. ${ }^{34}$ Most of the time, when a relative gets ill, all the family unite to face the adverse situation, together with the ill relative, taking into account the resonance and the impact in all the family components. ${ }^{6,20}$

Some family members taking part in this study stressed the assertive relationship between spouses as a potentiator, to make feasible the reciprocal cooperation, which is essential to strengthen the family. The literature stress that the family cohesion is identified when there is mutual support, compromise and collaboration between its members, helping the recovery of the sick relative. ${ }^{33,35}$ It was understood that the family cohesion can arise due to the need to face adverse situation and solve problems, constituting positive force to the family.

Moments of shared good mood in the family were also identified as foundations to the family members in this study, as it gives liveliness, stimulate then to keeps going and remain persistent. In fact, the families that experience constant episodes of suffering or struggle require creating time and space to share fun and joy to revitalize their spiritual energies, ${ }^{20}$ both physical and emotional.

The families stressed that the dialog with the PASs dependent must contemplate emotional control, expressed through a state of tranquility and low voice tone. The dialog also needs to make feasible the encouragement and empowerment of the dependent to strengthen him in his therapeutic process and everyday life. The data supported literature that stress that the voice tone must express optimism and care, transmitting joy and solace in the relationship. Besides that, the way the family communicates allows its members to show their ambivalent feelings that envelop tenderness, love, hope, gratitude, solace, happiness, joy, fear, anger, sadness. ${ }^{6,36}$

The inter-family communication is important both in nonverbal and verbal aspects. The family needs to be attentive to the intonation, choose adequate words and share experiences with the dependent, seeking to educate and promote a tranquil environment.

The limitations of this study are related to the homogeneity of the family sampled, that is, the lack of its dependent relative during the interview and the matter that the family members interviewed attend the CAPS AD. As this last aspect, the fact that the research have been performed in this service, where it is assumed that the families already receive emotional support and guidance, mainly through family group, could promote previous strengthen of the family members. In this case, posterior questions to be investigated imply in learning if the results would be different with families that seek help in primary health services, where not always one can count with this therapeutic resource of psychosocial care that the CAPS AD offers. This way, this research arouses future investigations in this context, in order to obtain new scientific evidence. However, the study gave voice to the families so they could express their strengths in the process of looking after its ill relative, despite living situations adverse of the psychoactive substance dependence. Such aspects need to be explored and included by the nursing practice and health professionals in its daily interventions.

\section{CONCLUSIONS AND IMPLICATIONS TO THE PRACTICE}

This study allowed learning that the families recognized that their facilitating strengths preceded the religious and spiritual practices' scope, the support played by the social support network and specialized health care, as well as the belief system shared by the family and the communicational and relational processes.

The perception of these family members demonstrated acknowledgement that its facilitating strengths make viable the process of family resilience, however, such fact implies that the addicted changed its attitude and behavior, feeding the coping actions by the family members. 
The relevance in comprehending the family forces subsides and instrumentalizes the clinical practice of the health professionals, mostly the nurses, in the process of empowerment of these families to discover their potential and handle the adverse situations dwelled in the context of drugs.

\section{FINANCIAL SUPPORT}

Scientific Initiation of the Institutional Program of Scholarship Scientific Initiation named- PIBIC, sponsored by Conselho Nacional de Desenvolvimento Científico e Tecnológico (CNPq National Council for Scientific and Technological Development) (Process no. 121115/2016-0).

\section{REFERENCES}

1. Laranjeira R, Sakiyama $H$, Padin MFR, Mitsuhiro S, Madruga CS. Lenad Família: Levantamento Nacional de Famílias dos Dependentes Químicos. São Paulo: Instituto Nacional de Ciência e Tecnologia para Políticas Públicas de Álcool e Outras Drogas (INPAD), UNIFESP [Internet]. 2013; [cited 2017 Jul 24]. Available from: http://inpad.org. br/wp-content/uploads/2013/11/PressFamilia.pdf

2. Malbergier A, Cardoso LRD, Amaral RA. Uso de substâncias na adolescência e problemas familiares. Cad Saúde Pública [Internet]. 2012 Apr; [cited 2017 Aug 27]; 28(4):678-88. Available from: http:// www.scielo.br/pdf/csp/v28n4/07.pdf

3. Paz FM, Colossi PM. Aspectos da dinâmica da família com dependência química. Estud Psicol [Internet]. 2013 Oct/Dec; [cited 2017 Jun 27]; 18(4):551-8. Available from: http://www.scielo.br/pdf/ epsic/v18n4/a02v18n4.pdf

4. Seleghim MR, Oliveira MLF. Influence of the family environment on individuals who use crack. Acta Paul Enferm [Internet]. 2013; [cited 2017 Aug 27]; 26(3):263-8. Available from: http://www.scielo.br/pdf/ ape/v26n3/en_10.pdf

5. Caravaca-Morera JA, Padilha MI. A dinâmica das relações familiares de moradores de rua usuários de crack. Saúde Debate [Internet]. 2015 Jul/Sep; [cited 2017 Aug 27]; 39(106):748-59. Available from: http:// www.scielo.br/pdf/sdeb/v39n106/0103-1104-sdeb-39-106-00748.pdf

6. Walsh F. Fortalecendo a resiliência familiar. 1st ed. São Paulo: Roca; 2005.

7. Zerbetto SR, Galera SAF, Ruiz BO. Family resilience and chemical dependency: perception of mental health professionals. Rev Bras Enferm [Internet]. 2017 Dec; [cited 2018 May 27]; 70(6):1184-90. Available from: http://www.scielo.br/pdf/reben/v70n6/pt_0034-7167reben-70-06-1184.pdf

8. Dias AB, Silva MRS. Processos familiares no contexto do transtorno mental: um estudo sobre as forças da família. Ciênc Cuid Saúde [Internet]. 2010 Oct/Dec; [cited 2016 Mar 9]; 9(4):791-8. Available from: http://periodicos.uem.br/ojs/index.php/CiencCuidSaude/article/ view/12047/7199

9. DeFrain J, Asay SM. Family strengths and challenges in the USA. Marriage Fam Rev [Internet]. 2007; [cited 2017 Aug 27]; 41(3/4):281307. Available from: http://www.tandfonline.com/doi/pdf/10.1300/ J002v41n03_04

10. Otto HA. What is a strong family? Marriage Fam Living [Internet]. 1962 Feb; [cited 2016 Mar 9]; 24(1):77-80. Available from: https://www.jstor. org/stable/pdf/348232.pdf

11. Valdez CR, Abegglen J, Hauser CT. Fortalezas familiares program: building sociocultural and family strengths in latina women with depression and their families. Fam Process [Internet]. 2013 Sep; [cited 2016 Mar 20]; 52(3):378-93. Available from: https://www.ncbi.nlm.nih gov/pubmed/24033237
12. Otto HA. Criteria for assessing family strength. Fam Process [Internet] 1963 Sep; [cited 2016 Mar 20]; 2(2):329-38. Available from: https:// onlinelibrary.wiley.com/doi/abs/10.1111/j.1545-5300.1963.00329.x

13. Minayo MCS. O desafio do conhecimento: pesquisa qualitativa em saúde. 14th ed. São Paulo: Hucitec; 2014.

14. Reis LA, Menezes TMO. Religiosity and spirituality as resilience strategies among long-living older adults in their daily lives. Rev Bras Enferm [Internet]. 2017 Jul/Aug [cited 2017 Aug 14]; 70(4):761-6 Available from: http://www.scielo.br/pdf/reben/v70n4/0034-7167reben-70-04-0761.pdf

15. Arrieira ICO, Thoferhn MB, Schaefer OM, Fonseca AD, Kantorsk LP, Cardoso DH. O sentido do cuidado espiritual na integralidade da atenção em cuidados paliativos. Rev Gaúcha Enferm [Internet]. 2017; [cited 2017 Aug 14]; 38(3):e58737. Available from: http://seer.ufrgs.br/ index.php/RevistaGauchadeEnfermagem/article/view/58737/44611

16. Shamsalina A, Norouzi K, Khoshknab MF, Farhoudian A. Recovery based on spirituality in substance abusers in Iran. Glob J Health Sci [Internet]. 2014 Jul; [cited 2015 Apr 2]; 6(6):154-62. Available from: https://www.ncbi.nlm.nih.gov/pmc/articles/PMC4825507/pdf/GJHS6-154.pdf

17. Monteiro RMP. A 'carreira moral' de jovens internos em instituições de recuperação para dependentes químicos. Dilemas - Revista de Estudos de Conflito e Controle Social [Internet]. 2017 Feb; [cited 2016 Apr 2]; 5(1):131-55. Available from: https://revistas.ufrj.br/index.php/dilemas/ article/view/7292/5871

18. Caldeira S. Cuidado espiritual - rezar como intervenção de enfermagem CuidArte Enferm. [Internet]. $2009 \mathrm{Jul} /$ Dec; [cited 2013 Dec 5]; 3(2):15764. Available from: http://bases.bireme.br/cgi-bin/wxislind.exe/iah/ online/?lsisScript=iah/iah.xis\&src=google \&base=BDENF\&lang=p\&n extAction=Ink\&exprSearch=20554\&indexSearch=ID

19. Borges MS, Santos MBC, Pinheiro TG. Social representations about religion and spirituality. Rev Bras Enferm [Internet]. $2015 \mathrm{Jul} /$ Aug; [cited 2016 Jul 9]; 68(4):609-16. Available from: http://www.scielo.br/scielo. php?pid=S0034-71672015000400609\&script=sci_arttext\&tIng=en

20. Walsh F. Family resilience: strengths forged through adversity. In:Walsh F, ed. Normal family processes. London: The Guilford Press; 2012. p. 399-423.

21. Ferrari EV. Religiões e hábitos alimentares: construção histórica. Rev Eletr Teol Ciênc Relig (Vitória-ES) [Internet]. 2016 Jul/Dec; [cited 2016 Jul 9]; 4(2):72-83. Available from: http://revista.faculdadeunida.com.br/ index.php/unitas/article/view/416/355

22. Moreno V. Relatives of patients with mental disorders: experiencing care at a Psychossocial Care Center. Rev Esc Enferm USP [Internet] 2009 Sep; [cited 2017 Aug 14]; 43(3):564-70. Available from: http:/ www.scielo.br/pdf/reeusp/v43n3/en_a10v43n3.pdf

23. Nascimento LTR, Souza J, Gaino LV. Relationship between drug dependence and alcohol users receiving treatment in a community health center specializing in alcohol treatment. Texto Contexto Enferm [Internet]. $2015 \mathrm{Jul} / \mathrm{Sep}$; [cited 2017 Aug 17]; 24(3):834-41. Available from: http://www.scielo.br/pdf/tce/v24n3/0104-0707tce-2015003610013.pdf

24. Alvarez SQ, Gomes GC, Oliveira AMN, Xavier DM. Grupo de apoio/ suporte como estratégias de cuidado: importância para familiares de usuários de drogas. Rev Gaúcha Enferm (Porto Alegre) [Internet]. 2012 Jun; [cited 2017 Aug 12]; 33(2):102-8. Available from: http://www.scielo. $\mathrm{br} / \mathrm{pdf} / \mathrm{rgenf} / \mathrm{v33n2/15}$.pdf

25. Paula ML, Jorge MSB, Albuquerque RA, Queiroz LM. Crack users in treatment: experiences, meanings and senses. Saúde Soc [Internet]. 2014; [cited 2017 Aug 21]; 23(1):118-30. Available from: http://www.scielo.br/scielo.php?script=sci_arttext\&pid=S010412902014000100118\&lng=en\&nrm=iso\&tIng=en

26. Alves RD, Morais TTM, Rocha SP, Rocha NNV, Duarte SR, Sampaio FFF. Grupos de familiares em CAPS ad: acolhendo e reduzindo tensões. SANARE [Internet]. $2015 \mathrm{Jan} / J u l ;$ [cited 2017 Aug 21]; 14(1):81-6. Available from: https://sanare.emnuvens.com.br/sanare/ article/view/613/330 
27. Siniak DS, Pinho LB. Emotional support received by families state of the crack users. J Nurs UFPE On Line [Internet]. 2015 Apr; [cited 2017 Aug 26]; 9(Supl 3):7656-63. Available from: http://www.lume.ufrgs.br/ bitstream/handle/10183/116458/000966087.pdf?sequence=1

28. Soccol KLS, Terra MG, Ribeiro DB, Mostardeiro SCTS, Teixeira JKS, Souto VT, et al. Sobrecarga financeira vivenciada por familiares cuidadores de indivíduos dependentes químicos. Rev Enferm UFSM [Internet]. $2014 \mathrm{Jul} / \mathrm{Sep}$ [cited 2017 Aug 21]; 4(3):602-11. Available from: https://periodicos.ufsm.br/reufsm/article/view/11264/pdf

29. Walsh F. Processos normativos da família: diversidade e complexidade. 4th ed. Porto Alegre: Artmed; 2016.

30. Silva EA, Rodrigues TP, Micheli D, Andrade ALM. Estratégias utilizadas no tratamento de famílias com usuários de substâncias. Psicol Pesq [Internet]. 2015 Dec; [cited 2017 Aug 23]; 9(2):198-204. Available from : http://pepsic.bvsalud.org/pdf/psipesq/v9n2/v9n2a10.pdf

31. Soccol KLS, Terra MG, Girardon-Perlini NMO, Ribeiro DB, Silva CT, Camillo LA. O cuidado familial ao indivíduo dependente de álcool e outras drogas. Rev Rene [Internet]. 2013; [cited 2017 Aug 25]; 14(3):54957. Available from: http://www.redalyc.org/pdf/3240/324027991011.pdf

32. Xavier MF, Rodrigues PHJ, Silva MCR. A percepção da família no tratamento e suporte de dependentes químicos. Enc Rev Psicol
[Internet]. 2015; [cited 2017 Aug 25]; 17(26):99-110. Available from: http://www.pgsskroton.com.br/seer/index.php/renc/article/ view/2419/2319

33. The Military REACH Team; The Research and Outreach (REACH) Laboratory; The University of Minnesota. Strong family functioning - Research brief. Supporting military families through research and outreach (REACH). [Internet]. 2014. [cited 2017 Aug 25]. Available from https://reachmilitaryfamilies.umn.edu/sites/default/files/rdoc/Strong\%20 Family\%20Functioning\%20\%282\%29.pdf

34. Silva PA, Silva MRS, Luz GS. Interações protetoras em famílias de alcoolistas: bases para o trabalho de enfermagem. Rev Enferm UER $J$ [Internet]. 2012 Apr/Jun; 20(2):191-6. Available from: http://www.epublicacoes.uerj.br/index.php/enfermagemuerj/article/view/4043

35. Trindade EMV, Costa LF. Considerações sobre a resiliência de adolescentes filhos de alcoolistas no contexto familiar. Comun Ciênc Saúde [Internet]. 2012 Apr/Jun; [cited 2017 Jul 23]; 23(2):179-88. Available from: http://bvsms.saude.gov.br/bvs/periodicos/revista ESCS_v23_n2_a09_consideracoes_sobre_resiliencia.pdf

36. Walsh F. Family resilience: a framework for clinical practice. Fam Process [Internet]. 2003; [cited 2016 Aug 23]; 42(1):1-18. Available from: http:// www.celf.ucla.edu/2010_conference_articles/Walsh_2003.pdf 